\title{
A NEW ACADEMIC STUDY ON THE HORROR GENRE: SUSPENSE BUILDING IN TWO NOVELS BY STEPHEN KING AND THEIR FILM ADAPTATIONS
} \author{
Scholars Publishing, 2019, 229 p. ISBN: 978-1527518018) \\ Boyka ILIEVA \\ South-West University "Neofit Rilski”, Bulgaria \\ E-mail: boyka@abv.bg
}

(Anastasova, Maria. The Suspense of Horror and the Horror of Suspense. Cambridge

In the beginning of 2019, the prestigious academic publisher Cambridge Scholars Publishing brought out the book of the young Bulgarian Americanist Maria Anastasova The Suspense of Horror and the Horror of Suspense - a study on suspense building in two novels by Stephen King and their film adaptations.

The research is significant and innovative in two aspects it is a valuable contribution to the literary criticism on King's work worldwide and to the theorizing of contemporary horror in Bulgarian literary studies. The book seems to fill an important gap in the existing otherwise impressive body of publications on the famous American writer as it focuses on a less explored aspect of his work - the ways of creating suspense. Moreover, this is the first in-depth research in Bulgaria on contemporary horror and suspense as an element of it.

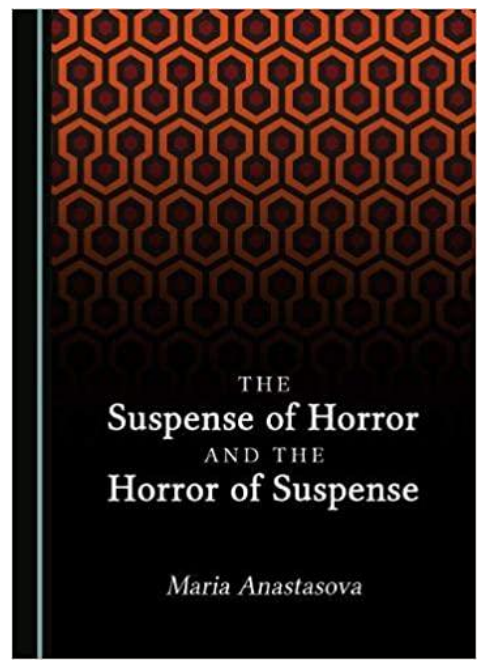

The author's interest in Stephen King's narration might be noticed in several previous articles of hers on various aspects of suspense generation in his novels. These works present an attempt at systematizing and analyzing the suspense motifs in the novel The Shining ${ }^{1}$ and in its film adaptation by Stanley Kubrick. ${ }^{2}$

The artistic basis for this suspense study is provided by two early novels of the horror author The Shining (1977) and Carrie (1974) and their film versions ${ }^{3}$. The first adaptations of the two novels were made two or three years after their publication, while the second ones two and even almost four decades later, respectively. This significant time gap between both cinematic productions of the same novel favors the tracing of suspense building on three different levels - 1. literary work; 2. early film adaptation; 3. more recent film adaptation. Furthermore, the analysis of distant in time film productions must undoubtedly take into consideration both the change in aesthetic tastes and the possible ideological transformations (2). ${ }^{4}$

The book's length is 229 pages and it is well-organized in a logical structure - an introduction, five chapters, a conclusion, and three appendices.

The first chapter outlines the theoretical framework of the study and supports its choice with arguments paying specific attention to the terminological clarification and theoretical use of the term suspense. For the adequate fulfillment of her research aims, Anastasova relies on various academic

\footnotetext{
${ }^{1}$ Anastasova (2015) The Hedge Animals as a Suspense Motif in Stephen King's The Shining. // Езиков свят, T. 13, № 1, c. 61-66; Anastasova (2016) Patterns of creating suspense in Stephen King's The Shining. // English Studies at NBU, Vol. 2, № 1, pp. 43-58.

${ }^{2}$ Anastasova, Maria (2016) Room 237 as a Gradually Developed Suspense Motif in Stanley Kubrick's The Shining. // Езиков свят, Т. 14, № 1, с. 60-67.

${ }^{3}$ The Shining (1980) directed by Stanley Kubrick; The Shining (1997) directed by Mick Garris; Carrie (1976) directed by Brian de Palma; and Carrie (2013) directed by Kimberly Peirce.

${ }^{4}$ The numbers in brackets indicate the page of quotation from Maria Anastasova's The Suspense of Horror and the Horror of Suspense. Cambridge Scholars Publishing, 2019, 229 p.
} 
fields - theory of suspense, literary narrative theory, and theory of film narration. It is worth noting that the volume of the studied scientific material is as impressive as the diligence with which it seems to have been examined and employed to achieve the book's goals. A few words need to be mentioned about the theoretical corpus of the analysis, which presents a valuable contribution to Bulgarian literary studies. The comprehensive review of the current research on horror and suspense might serve as a solid theoretical basis for the future studies in these areas.

In her desire for absolute lucidity and precision, the author has subdivided the chapter into four parts, which summarize the main theories of suspense, horror, novel analysis, and film analysis, respectively. She has provided a broad overview of the various definitions of suspense and the way it operates in fiction, some of which (Dolf Zillmann) searching its emotional closeness to Aristotle's fundamental concept of catharsis. The list of distinguished contemporary scholars whose ideas are the subject of attention in the book is impressive - Aaron Smuts, Andrew Ortony, Gerald Cupchik, Hans Wulff, Roland Barthes, David Lodge, Noël Carroll, Dolf Zillmann, William Brewer, etc. For her further analysis, Anastasova decides to employ Noël Carroll's conceptual framework because of its precision and comprehensiveness (20). Taking as a starting point the distinction between suspense as an emotional experience in real life and suspense as an emotional response to an artistic narrative, Carroll formulates a complete and extremely detailed definition of the term, which is used by Anastasova for the identification of suspense episodes in the works in question.

In the course of explaining the specifics of the horror genre, Caroll's concept erotetic narration is introduced, which refers to the connection of "scenes, situations and events" that have appeared earlier in the story with those that appear later, on the principle of questions and answers (25). In this regard, he distinguishes two types of questions associated with the narrative - macro-questions, related to the general outcome and the end of the story, and micro-questions, related to the unraveling of different intermediate episodes within the general narrative.

The third part discusses the theories of literary narration in search for a proper toolkit for the further novel analysis of the suspense motifs and episodes. Here priority is given to Gerard Genette's literary narration concepts and terms like focalization (referring to the point of view), voice (referring to the narrator), and narrative time (including the components order, duration, and frequency).

Special attention should be paid to the fourth part of this chapter, in which the author offers her own theoretical model for the purposes of the film analysis. It is primarily based on the slightly modified postulates by David Bordwell and Edward Branigan, which are related to the theory of literary narration. Anastasova has developed further this toolkit to suit the needs of her film analysis (32). Regarding terminology, she prefers the more commonly used fabula and syuzhet in the filmic suspense analysis. An important semantic distinction is drawn between the use of the term diegesis in film analysis ("the implied world of the story, including setting, characters, sounds and events" - p. 32), and its meaning in literature. The elements that are outside this imaginary world are defined as non-diegetic or extradiegetic.

Chapters Two and Four present the literary analysis of the two novels and their structure is identical - after a brief overview of the critical reception, an analysis of the themes, plot lines and narration is offered with an emphasis on suspense building.

With regard to the narration in both novels, the author observes that variable focalization is typically employed and sporadic instances of multiple focalization can also be identified. The suspense analysis of King's The Shining brings out three types of suspense motifs and episodes - 1 . GRADUALLY DEVELOPED SUSPENSE MOTIFS (GDSMs) - which unfold in the course of several chapters that do not come in succession; 2. CLIMACTIC SUSPENSE EPISODES (CSEs) - which occur in the framework of one or two consecutive or close chapters, most often close to the denouement and end of the book, and 3. MINI SUSPENSEFUL EPISODES (MSEs) - presenting short, stressful situations in chapters with different focus (74-75). Unlike The Shining, in Carrie the use of only the first two types of suspense motifs and episodes (GDSMs and CSEs) can be traced. Anastasova observes that they appear only in the so-called main narrative (the narrative following the main story line in the novel). The author offers a precise systematization of the suspenseful motifs and episodes in the novels 
explaining that the three types of episodes function in combination, and sometimes (in The Shining) suspense operates together with horror. Additionally, the manipulation of time is of key significance for suspense building in Carrie (157).

Chapters Three and Five deal with the film adaptations of the two novels, The Shining - directed by Stanley Kubrick (1980) and Mick Garris (1997), and Carrie - directed by Brian De Palma (1976) and Kimberly Peirce (2013). Both chapters examine the adaptations considering the basic directorial decisions and critical reception, and try to analyze suspense with regard to the identified types of suspense motifs and episodes. Film frames are used to illustrate the author's comments. Once again, Anastasova offers intriguing summaries comparing the suspense motifs and episodes of the novels with those in the film versions. In three of the four cinematic adaptations, the directors have mostly preserved the GDSMs from the books and Kubrick's version of The Shining appears to be most experimental - it has replaced or completely removed them. The CSEs, on the other hand, are almost fully reproduced in the movies.

The techniques applied to generate suspense in literature and cinema have their own specifics. In the novels they largely depend on the focalizer, while in the film adaptations the vision of the director is decisive. Among the basic literary means of suspense building are "intertextual references, introduction of long descriptions, focus on feelings, or memories to interrupt the main action, interior monologue, punctuation" (204).

Anastasova has provided an intriguing summary of the employed techniques that tend to distinguish the artistic style of the different directors. While Kubrick particularly relies on "symmetry, color, long view, extradiegetic sounding and facial expressions", Brian De Palma takes advantage of "deep space composition, split screen and slow motion" (204). Mick Garris's obvious priority is being faithful to the literary work allowing few deviations from it, which, however, has not resulted in a more intense film version (205). The author underscores that in her directorial choices Kimberly Pierce engages in a dialogue with the previous film adaptation of De Palma rather than with King's work, i.e. she "adapts the adaptation" (205). The innovations she introduces (in terms of portraying the characters and their relationships) tend to shift the focus and are often at the expense of suspense (204-205).

Although literary works usually rely strongly on the reader's imagination and films show a ready-made matrix of situations, some common suspense provoking narrative techniques can be identified, such as parallel editing and the manipulation of time (204-205).

Stephen King's writings have been a constant temptation for the young researcher, as evidenced by her latest publication, which expands significantly the scope of her academic work. It demonstrates an attempt at establishing intertextual correlations in E. A. Poe's story The Fall of the House of Usher and Stephen King's The Shining. Based on interesting comparisons about the topos of action as the bad place, the author has come to the curious conclusion that the seemingly identical collapse of the buildings in the end of the two literary works may provoke entirely different interpretations. If in Poe the collapse of the manor could be taken as a sign of the total and irreversible destruction of the character's psyche, in King's novel, the collapse of the hotel seems to suggest a more optimistic interpretation - the hope of overcoming evil. ${ }^{5}$

The outlined new research directions reveal a vivid creative spirit and could be a promise of a new valuable study.

\footnotetext{
${ }^{5}$ Анастасова, М. (2020) Идеята за злото място в разказа „Рухването на дома на Ашър“ на Едгар Алан По и в романа „Сиянието“ на Стивън Кинг. // Езиков свят, Том 18, № 2, с. 89.
} 